\title{
Workshop prepares ground for human proteome project
}

Alison Abbott

Plans to decipher the human proteome were explored at a meeting earlier this month organized by the recently created Human Proteome Organisation (HUPO).

About 100 researchers and officials gathered in Leesburg, Virginia, on 7 October to discuss a protein equivalent of the Human Genome Project. But participants warned that the initiative could take years to set up.

"The decision to launch the Human Genome Project

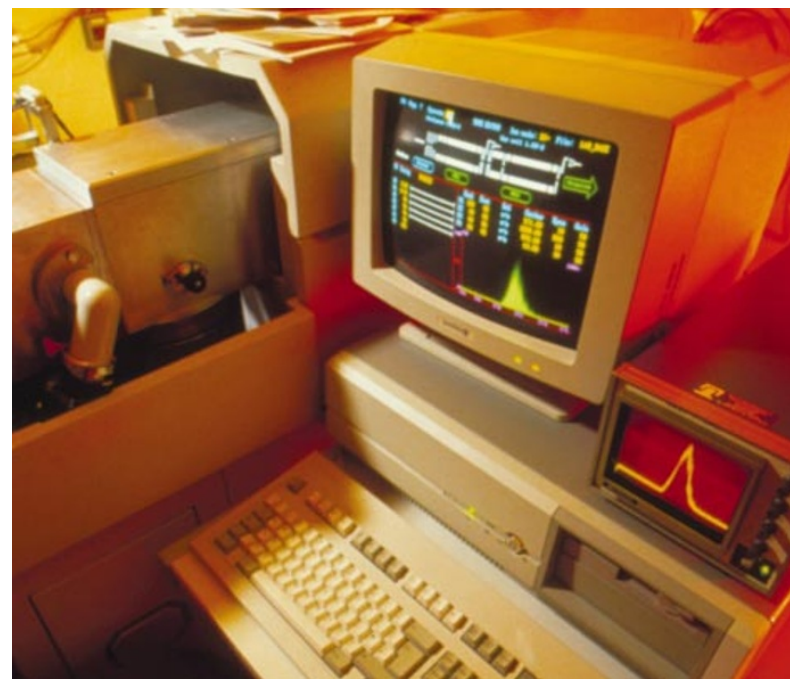

was made after no less than two years of discussion, followed by three years of pilot effort," said Sam Hanash, a cancer specialist at the University of Michigan, who in June was elected as HUPO's first president. "HUPO knows it is important to proceed step by step."

Understanding the proteome - the pattern of proteins produced by a cell under particular conditions - would accelerate drug discovery, Bernard Schwetz, acting principal deputy commissioner of the Food and Drug Administration, told the workshop.

Participants agreed that HUPO should help to organize an international human proteome project, from which all data would be made freely available - but that there should be a planning and piloting phase before the launch of a full-blown project.

The planning phase will identify model systems - one or two human cell types and a subset of proteins, such as those representing a specific pathway or subcellular compartment. The three key areas of proteomics - protein expression, protein function and databasing - would then be piloted in these models. "This is a good way to test feasibilities and build up technologies," says Joshua LaBaer, director of the Institute of Proteomics at Harvard Medical School in Boston.

In practice, one pilot project is already under way. This is the Alliance for Cellular Signalling, a multidisciplinary, multilaboratory initiative that is creating a database of the properties of proteins involved in cellular signalling in certain mouse cells (see Nature 402, 219-220; 1999).

The alliance is keen to cooperate with the proteomics project. "We have a head start on the issue," says Ron Taussig, associate director of the alliance and a cell

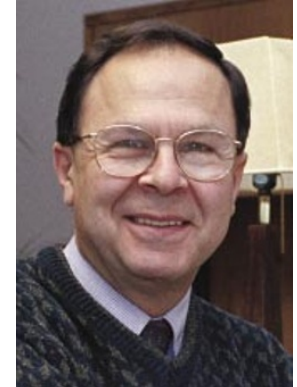

No rush: techniques such as mass spectrometry (above) will need to be marshalled for use in proteomics prompting Sam Hanash (left) to stress the need for patience.

biologist at the University of Texas Southwestern Medical Center in Dallas. "We will make all our databasing knowledge available," he adds.

Unlike the Human Genome Project, which relied on one basic technology for gene sequencing, proteomics uses many new technologies, not all of which have been optimally developed.

Early doubts among some researchers that a single international project could handle the diverse faces of proteomics have been dismissed by participants at the meeting. But Francis Collins, director of the National Human Genome Research Institute in Bethesda, Maryland, cautions that the necessary technologies will have to be identified and proven before the project can be scaled up to high throughput.

Leroy Hood, president of the Institute for Systems Biology in Seattle, Washington, says that for the proteome project to succeed it will have to be both ambitious and tightly focused.

HUPO hopes to assist the project by helping to coordinate activity internationally and by offering advice to potential funders of the work. It also plans to organize training www.hupo.org programmes in proteomics technologies.
Confusion over law leaves stem-cell research in the lurch

Xavier Bosch, Barcelona

A dispute between Spain's ministries of health and science has left the country's stem-cell researchers unsure of the legal status of their work.

About a dozen research groups in Spain are thought to be working with imported human embryonic stem cells, but they face an uncertain future after health-ministry officials suggested in August that one group was in breach of the law. The science ministry has since defended the work, but admits that the law governing the research is unclear and out of date.

The problem arose when Bernat Soria, head of the Bioengineering Institute at Miguel Hernández University in Alicante, spoke about his use of human embryonic stem cells in diabetes research at a conference in July at the University Rey Juan Carlos in Madrid. When the press covered Soria's presentation, they drew attention to the fact that Soria was using human embryonic stem cells. He had obtained the cells from the Israel Institute of Technology in Haifa.

In response to the reports, the health ministry ordered Soria to suspend his work and launched an inquiry. Soria says that health-ministry officials told him that the importation of the cells breached a 1988 law on assisted reproduction. The science ministry defended Soria's research, but has not denied that importing the cells may have been illegal. Soria is now looking for a lawyer to help resolve the issue.

The health ministry's inquiry has since been closed following a statement from Miguel Hernández University that no work using human embryonic stem cells has been carried out on its premises. The statement, and the university's failure to publicly back his work, has angered Soria. "Officially, I have not been conducting such research and I have not used embryonic stem cells," he says.

Ramon Marimon, state secretary at the science ministry, has said that a dozen groups are using stem cells in Spain. The researchers have not been publicly identified, but are all believed to be using imported stem cells, as extracting them may also be illegal under the 1988 law.

A 1998 report for the health ministry, written by the National Commission on Human Assisted Reproduction, recommended that the law be updated to allow extraction "as soon as possible". But divisions in the government are said to have blocked its implementation. 